\title{
Methodology of Cross-Cultural Description of Speech Behaviour: A Case Study of Invitation in German and Russian Discourse
}

\author{
Elizaveta Kotorova \\ e.kotorova@gmail.com \\ University of Zielona Góra, Poland \\ $\&$ \\ National Research Tomsk Polytechnic University, Russia
}

\begin{abstract}
The article aims to demonstrate a consistent methodology for conducting cross-cultural research of verbal communication behaviour and identifying its peculiarities in different language cultures. First of all, the author discusses the problem of defining a basic unit of communication crucial for the analysis of communicative behaviour and proposes her own interpretation of such a unit called speech behaviour pattern (SBP). The illocutionary content and general organization of any SBP is considered universal, while their actual realization in a language is culturally conditioned and therefore may vary significantly in different languages. Utterances that constitute a certain SBP are organized into a field with a prototypical centre and a gradationally formed periphery, which is referred to as communicative-pragmatic field (CPF). The proposed methodology of contrastive analysis includes the following four major components: 1) definition of illocutionary purpose, 2) description of structural forms of SBP (i.e., their lexical and grammatical characteristics), 3) identifying communicative-pragmatic factors, 4) description of the structure and hierarchy of the communicative-pragmatic field that includes utterances implementing SBP. The presented approach is then consistently applied to the analysis of the SBP of INVITATION in the Russian and German discourse. The language data are taken from the existing Russian and German corpora. The proposed methodology helps to identify the main similarities and differences in the implementation of the SBP INVITATION in Russian and German driven by grammatical and communicative-pragmatic factors.
\end{abstract}

Keywords: speech behaviour; cross-cultural communication; contrastive analysis; Russian; German

\section{INTRODUCTION}

Ongoing socio-cultural integration processes in the world are marked by increasing contacts between people of different nations and cultures. In order to successfully implement such contacts and to avoid communication failures, one needs not only to possess proficiency in a foreign language, but also to be acquainted with the peculiarities of communicative behaviour of a given nation: "Cross-cultural communication challenges are not limited to difficulties of translations. Communication difficulties can continue even after mastering a language's vocabulary and grammar. One needs to grasp not only the literal meanings but also the social context and subtle possible misinterpretations" (Merkin, Taras \& Steel, 2014, p. 1). Of particular importance in this case is the knowledge of main speech behaviour patterns (such as REQUEST, GRATITUDE, AGREEMENT etc.), which are the most important integral part of verbal behaviour. Being unfamiliar with habitual discourse strategies and speech behaviour patterns of a foreign culture can lead to serious communication problems and even provoke culture shock. Therefore, developing intercultural competence, i.e., the ability to communicate effectively across cultures, is a high priority for the language studies and education in the $21 \mathrm{st}$ century (cf. Catana, 2014; Suchankova, 2014, p. 1439). 
The beginning of cross-cultural studies on SBPs was marked by the project "Requests and Apologies: A Cross-Cultural Study of Speech Act Realization Patterns" in the 1980s. It was based on the data of English, French, Danish, German, Russian, and Hebrew (Blum-Kulka / Olshtain 1984). Subsequently, the basic principles and methods developed within this project have been used in descriptive and comparative studies of other languages.

In the following years, cross-cultural and intercultural communication has been studied from different perspectives, the focus being on cross-cultural differences in speech behaviour such as individualism vs. collectivism as a characteristic feature of socio-culture, direct vs. indirect communication, the face-saving concept, the concept of power distance and others (cf. Merkin, Taras \& Steel, 2014; Lulu, Alkaff 2019). A new and promising direction is the study of the impact of digitalization on cross-cultural communication processes (cf., for example, Lifintsev \& Wellbrock 2019). However, modern cross-cultural studies have not created a methodology that covers all or at least most of the aspects that are important for contrastive description of speech behaviour in different language societies. This paper proposes such a methodology, covering different sides and aspects of speech behaviour, both linguistic and cultural.

The main goal of this article is to demonstrate a consistent methodology for conducting intra- and cross-cultural analysis of verbal communication behaviour and identification of its peculiarities in different language cultures. This methodology is based on the concept of speech behaviour pattern (SBP for short) and includes four components: 1. Definition of communicative purpose of a certain SBP and identification of the differences this purpose exhibits in comparison to that of the other patterns; 2. Description of structural forms of this SBP (i.e. its lexical and grammatical characteristics); 3. Identifying communicative-pragmatic factors influencing the choice of an utterance implementing this SBP; and 4. Description of the structure and hierarchy of the communicative-pragmatic field that includes utterances implementing this SBP.

All the relevant data used in the study were obtained from the national corpora of the respective languages. They include the IDS corpora (Cosmas II and DGD-corpus) and the DWDS core corpus for German and "Nacional'nyj korpus russkogo yazyka" (National Corpus of the Russian Language) for Russian.

The size of the corpora ensures a comprehensive and scientifically verifiable analysis as they contain, firstly, data from both written texts and oral communication; secondly, in addition to simple units (words and word forms), they allow searching for complex expressions (collocations and word combinations); and, thirdly, they contain information both in relation to the number of excerpted types and tokens and in relation to their distribution over time in the corpus materials.

Most of the examples used in the present study were extracted from concordances made with the help of the corpora. Key words (e.g., performative verbs) and word combinations that can contain neighbouring words or words separated by other lexical units served as nodes for creating these concordances. It should be noted that certain examples in the article are presented in a shortened and slightly modified form, which does not affect their meaning. In some rare cases, examples were taken from native works of fiction or from authentic websites.

In what follows, the article provides a description of this methodology and each of its components as well as illustrates the possibilities of its application through the example of the SBP of INVITATION in German and Russian. 


\section{BASIC UNIT FOR ANALYSIS OF COMMUNICATIVE SPHERE: MAIN THEORIES OVERVIEW ${ }^{1}$}

Recent linguistic studies show an increased interest to analysing forms of oral and written communication as well as to studying the usage conditions of language means in intra-, inter-, and cross-cultural communication. This approach inevitably entails the need to single out and identify basic units of the communicative sphere which could be used for the analysis of verbal behaviour of both individuals and language communities. Generally, in verbal communication, it is the utterance that is considered to be a minimal unit, because it is closely related to the speech situation, background knowledge of the speaker, his goals, and attitude towards the world (cf. among others Lyons, 1995, p. 36-40; Bakhtin, 1996, p. 159; Drid, 2018, p. 13). This section outlines some of the most prominent approaches to defining a basic unit used for the analysis of communication.

The concept of utterance, especially in the early stages of the development of communication theory, was often associated, and sometimes even equalled to, with the concept of speech act: "The universum of speech does not form oneself from words or sentences, it forms itself from utterances (speech acts)"' (Wierzbicka, 1983, p. 125). According to this interpretation, the term speech act stands for some specific communicative action that realizes a certain intention (or illocutionary purpose in terms of the theory of speech acts) of the speaker. Searle (1965), while pointing out that by speech acts he means, first of all, illocutionary acts, notes that "the production of the sentence token under certain conditions is the illocutionary act, and the illocutionary act is the minimal unit of linguistic communication (p. 222)." However, in the course of the development of the speech act theory, it became clear that the same communicative (i.e., illocutionary) purpose can be expressed in different ways. Therefore, the notion of speech act has also developed a broader meaning, namely, that of a set of utterances implementing one and the same communicative purpose. In this situation, the very form of the term (i.e., speech act) has become misleading (cf. Lyons, 1995, p. 235), since its content indicates not only the act itself, or the process of utterance production, but rather a functional unity of utterances. This also found reflection in the fact that instead of speech act, many of subsequent works within this framework started to use either the term speech action (e.g., Bührig, 2005; Witczak-Plisiecka, 2014) or speech act set (e.g., Murphy \& Neu, 1996; Olshtain \& Cohen, 1983; and others).

The question about identifying the basic unit of speech communication has also been raised by authors within other theoretical frameworks. For example, in the 30s-40s of 20th century, the Russian linguist Mikhail Bakhtin, almost in parallel to Austin and Searle's speech act theory, developed the theory of speech genres, which only recently started to receive attention outside Russia (Dönninghaus, 2001, p. 69; cf. also Faraco, 2017 and others). Within this theory, Bakhtin introduced the concept of speech genre. This concept likewise regards the utterance as the minimal communication unit. However, Bakhtin does not restrict speech genre to the notion of utterance; rather, he considers it as an umbrella term: "Every single utterance is, of course, individual, but each sphere of language usage develops relatively stable sets of such utterances of its own, it is those we call speech genres" (Bakhtin, 1996, p. 159). Similar to speech act, the term speech genre is likewise rather ambiguous and has no clear-cut boundaries. Bakhtin (1996) acknowledged this by noting "the extreme heterogeneity of speech genres", to which he attributed "short turns of everyday dialogue, [...] a short standard military command, a detailed order, a varied repertoire of business documents, [...] diverse forms of

\footnotetext{
${ }^{1}$ The present overview is limited to only the theories related to the problem of defining a basic unit for the analysis of communication as its organization is crucial for the methodology of the study and do not consider any of the previous methodologies aimed at contrastive analysis. ${ }^{2}$ All non-English citations are translated by the author.
} 
scientific presentations and all the genres of literature (from a proverb to a multivolume novel)" (p. 159-160).

It is also important to emphasize that neither the theory of speech acts, nor the theory of speech genres in their classic versions were aimed at studying how the proposed basic units (i.e., speech acts and speech genres) are realized in different languages. For example, Austin and Searle developed their theory solely using data from English, while Bakhtin based his theory on the Russian language. Their followers, however, sought to use these minimal units as the basis for contrastive analysis of the forms that realize them in different language pairs. Although, in general, these comparative studies have been rather successful, it has become clear that each of the models requires a certain amount of refinement and adaptation to be used in contrastive study of languages.

\section{SPEECH BEHAVIOUR PATTERN AS A BASIC UNIT OF COMMUNICATIVE- PRAGMATIC ANALYSIS}

Nevertheless, despite the existence of the approaches discussed in the previous section, there is still need for an effective algorithm that would ensure receiving more or less consistent results in the analysis of communicative behaviour in different cultures and languages. In the present article, we propose such an algorithm and bring it up for discussion. The algorithm is based on the description of a unified basic unit of communication that we refer to as speech behaviour pattern (SBP) and the way it is realized in communication (for further details, seeGladrow \& Kotorova 2017).

Based on the analysis of the basic units described in the previous section, we define a speech behaviour pattern as a set of verbal (and/or non-verbal) actions covering everyday situations of interpersonal communication within a relatively small time interval. Thus, the concept of SBP is narrower than that of speech genre. It is similar to the idea of a 'set of speech acts' presented in the works by the followers of Austin and Searle. Still, unlike the said model, SBP possesses a certain structure, as it will be shown further. If we compare SBP with the notion of Ehlich and Rehbein's 'speech action model', it should be pointed out that SBP is not only intended for the analysis of various types of monolingual discourse. It can also serve as a basis (Tertium Comparationis) in contrastive, cross-cultural studies of communicative behaviour which is of particular importance in teaching cross-cultural communication to representatives of different linguacultural communities.

Any SBP is constituted by a set of elementary utterances expressing a common communicative purpose. The choice of a specific utterance out of the set is determined by this purpose, communicative-pragmatic factors, and the structure of basic grammatical constructions belonging to a given SBP.

Typical SBPs are represented by speech acts such as PROMISE, REQUEST, THREAT, etc. that have been widely discussed in pragmalinguistics. ${ }^{3}$ In what follows, the algorithm is illustrated by applying it to the contrastive description of the SBP of INVITATION in German and Russian.

\footnotetext{
${ }^{3}$ The definition of pragmalinguistics is used in Kasper \& Roever's (2005, p. 317-318) sense: "knowledge and ability for the use of conventions of meanings (e.g., the strategies for realizing speech acts) and conventions of forms (e.g., linguistic forms implementing speech act strategies)".
} 


\section{DEFINING AND DESCRIBING COMMUNICATIVE PURPOSE}

\section{NATURAL SEMANTIC METALANGUAGE AS A MEANS TO DESCRIBE COMMUNICATIVE PURPOSE}

The organizing factor of SBP is its communicative purpose. A particular utterance can be attributed to a specific pattern solely by virtue of the intention pursued by the speaker saying it. An important issue here is the need for semantic explication of each particular purpose, i.e., it is necessary to define what is meant by illocution of PROMISE, REQUESTS, THREAT, etc. These definitions should be maximally universal and culturally independent. Besides, they should be formulated as consistently as possible with respect to different SBPs.

As a possible basis for describing the communicative purpose of SBP, the use of the Natural Semantic Metalanguage theory by Anna Wierzbicka is suggested (Goddard \& Wierzbicka, 2016). Wierzbicka consistently tested the NSM theory by describing and comparing various speech genres and speech acts (cf., for example, Wierzbicka, 1983, 1985, etc.). Using NSM, she made semantic explications, for example, for REQUEST, CAUTION, ADVICE, etc. However, as of yet, no unified catalogue of definitions for various speech acts (in Wierzbicka's terms) has been put together. An important attempt in this regard was the dictionary of English speech act verbs (Wierzbicka, 1987). It should be noted, though, that it does not provide universal concepts, since the author analyses concrete verbs of a specific language. In addition, one should keep in mind that in order to implement one and the same SBP, different languages may employ a different set of verbs with certain differences in the semantic explication, cf. for example, Ger. vorschlagen and Eng. suggest / propose.

In addition to a set of conceptual primitives, the NSM framework provides specific rules that regulate how basic units should be combined to express a particular meaning. In that way a list of canonical contexts or canonical sentences is compiled. In most cases, they have the form of a formula with the subject expressed by the pronoun in the first person singular, and predicate in the present tense with or without modalization ${ }^{4}$, for example, I think that you can do it. I say: I want you to do it, etc. Thus, for each SBP, it is necessary to develop a definition of its communicative purpose on the basis of the list of semantic primitives and the rules for constructing canonical sentences.

It should be emphasized that it is very hard to completely avoid cultural specificity in characterizing SBPs. Firstly, the conception of each SBP is to some extent culturally determined, as demonstrated by Wierzbicka for APOLOGY in Japanese and European languages (Vežbickaja, 1999, p. 655-662). Secondly, the set of semantic primitives to some extent reflects the specifics of the natural language it represents. However, when making a contrastive study of SBP in two or more languages, it is important to strive for as universal definition of the communicative purpose as possible.

\section{INVITATION AMONG DIRECTIVE SBPS}

Before proceeding to the description of the communicative purpose of INVITATION using NSM, a short overview of this SBP in comparison to other directive SBPs is provided. The place of INVITATION is determined differently depending on a classification of speech acts and communicative patterns. In the classical taxonomy of Searle, INVITATION belongs to the class of directive speech acts (Searle, 1979, p. 13-14). However, he does not make any distinction between single communicative patterns within a speech act class. In Harras et al. (2007, p. 170), the paradigm of INVITATION is characterized as a "specific (mental) attitude of the speaker that $\mathrm{P}$ is in the interest of the speaker and the hearer, where $\mathrm{P}$ is a mutual activity of $\mathrm{S}$ and $\mathrm{H}$ ".

\footnotetext{
${ }^{4}$ The notion of modalization is understood here as the process of imparting a modal meaning to a language construction (cf. Nuyts 2016 ).
} 
Hindelang considers INVITATION as a variant of PROPOSAL and distinguishes two types of this speech act: 'problem solving suggestion' and 'motivating proposal' (with INVITATION belonging to the second type). He also makes the following important comment with respect to differentiation of these speech acts: "A motivating proposal is to be considered an INVITATION, if Sp1 creates or provides necessary material conditions for the realization of the mutual activity and perhaps takes care of the common costs or duties that may arise" (Hindelang, 1978, p. 470-471). This can be a suggestion to visit, to stay, to spend time together or to have some mutual activity, and so on.

This distinctive feature, i.e., that the speaker commits himself to taking care of the hearer and bringing him pleasure in the event of an INVITATION, is the reason why, in addition to the directive component, this pattern also contains a certain commissive one. This peculiarity may be decisive in certain situations for distinguishing INVITATION from PROPOSAL, cf.:

a. Ich kenne ein nettes Restaurant „Chez Gino “, wo man abends problemlos einen Platz bekommt, und schlage vor, dort hinzufahren. [I know a nice restaurant "Chez Gino", where you can easily get a place in the evening, and I propose going there.]

b. Ich kenne ein nettes Restaurant ,Chez Gino “, wo man abends problemlos einen Platz bekommt, und ich lade dich zum Abendessen ein. [I know a nice restaurant "Chez Gino" where you can easily get a seat in the evening and I invite you for dinner.]

(2) a. Predlagaju pojti v restoran potantsevat', zakažem čto-nibud' lëgkoe. [I propose going to a restaurant to dance, we'll order something "light".]

b. Priglašaju tebja pojti v restoran potancevat', zakažem čto-nibud' lëgkoe. [I invite you to go to a restaurant to dance, we'll order something "light".]

In the situations illustrated in (1a) and (2a), it is not clear who is going to settle the bill in the RESTAURANT; most likely, the costs will be shared, so it should be considered a proposal. However, in (1b) and (2b), the speaker wishes to emphasize his intention to pay the restaurant bill, therefore in this case we deal with an INVITATION.

In his definition of INVITATION, Wagner, (2001, p. 208) also notes that the speaker takes a greater responsibility for preparation, realization, and costs of the upcoming activity. However, according to him, INVITATION should be classified as a sub-category of REQUEST.

In addition to this feature, the difference between these two SBPs is that in the case of REQUEST ( $3 b$ and $4 b$ ), the future activity is usually only in the interest of the speaker, while in the case of INVITATION ( $3 a$ and $4 a$ ), the speaker at least hopes that the hearer is also interested in this activity and that it will be pleasant for him, cf.:

a. Wir laden Sie herzlich ein, an der Konferenz teilzunehmen, die im Europahaus (Unter den Linden 78) stattfinden wird. [We cordially invite you to attend the conference, which will take place at the Europahaus (Unter den Linden 78).] b. Wir bitten Sie herzlich darum, uns durch Ihre Präsenz bei unserer Veranstaltung zu unterstützen. [We kindly ask you to support us with your presence at our event.]

(4) a. Priglašaju tebja projti k tomu stoliku. [I invite you to go to that table.]

b. Radi boga, ja prošu tebja, prohodi von tuda, $k$ stoliku. [For God's sake, I'm asking you to go there, to that table.]

This fact was also pointed out by Wierzbicka in her analysis of the English verbs ask $(\approx$ bitten, prosit') and invite $(\approx$ einladen, priglashat' $)$. She notes that the semantics of the two verbs differ in the following two respects. First, in the situation of REQUEST, the speaker is much more interested in the desired action to take place than in the situation of INVITATION. Second, with REQUEST, the speaker considers the upcoming activity as beneficial to himself, 
while with INVITATION, the activity is regarded as beneficial for both himself and the hearer (Wierzbicka, 1987, p. 82).

Thus, INVITATION can be characterized as a non-obligatory demand with a bi-directional preference, which may have a certain commissive component in some cases.

\section{COMMUNICATIVE PURPOSE OF THE SBP OF INVITATION}

Wierzbicka (1987, p. 82) notes there are two types of INVITATION: one can invite someone to come to a place and one can invite someone to do something. In what follows, the first subtype is referred as LOCUS INVITATION, and to the second one as is referred ACTUS INVITATION. Some definitions of INVITATION consider only the first type (cf., e.g., Purkert, 1990, p. 154, 157). However, it is assumed that a coherent definition of INVITATION for both subtypes should be formulated.

In addition to the features discussed for the SBP of INVITATION earlier, the following must also be taken into account in the definition:

(1) It is assumed that the hearer is not going to carry out the speaker's desired action by himself. As a rule, an inducement is needed on the part of the speaker, he proves to be the person who dominates in the given communicative situation. In fact, I can invite you to my house because I have the right to determine who is allowed to enter my house. Likewise, I can invite you to a trip if I have gathered all the necessary information, possibly also made certain preparations or have financial possibilities to do so, etc.

(1) It is assumed that the hearer is willing to perform the upcoming activity. Wierzbicka notes "if I invite you to do something, I am not really saying that I want you to do it. Rather, I am saying that I would want you to do it - if you want to do it" (Wierzbicka, 1987, p. 82). That is why the speaker is not necessarily disappointed or annoyed, when the hearer does not make the desired action.

Based on Wierzbicka's definition of the verb invite and the analysis conducted, the following formulation for the communicative purpose of INVITATION as an SBP are proposed:

(a) I assume that you do not do that when I do not say I would want you to do that

(b) I suppose this will be good for you

(c) I know you do not have to do that

(d) I do not know whether you will do that or not

(e) I would like you to do that - if you want to do that.

\section{STRUCTURAL FORMS OF SBP}

\section{BASIC GRAMMATICAL CONSTRUCTIONS BELONGING TO SBP}

Each SBP is realized in certain basic grammatical constructions. The set of these constructions varies from pattern to pattern. For example, the majority of directive SBPs are typically realized as imperatives, while assertive acts are often expressed by means of declarative sentences. It should be noted that performative verbs are not characteristic for every SBP structure. While most SBPs are indeed prototypically realized with the help of a performative verb (e.g., CONGRATULATE, APOLOGY), in some cases it is not possible to use the verb indicating the purpose of communication as a performative (e.g., THREATEN, DECEIVE). 
In the full performative formula ${ }^{5}$ of any SBP, it is usually possible to identify the following four components: Action, Speaker, Hearer, and Reason (to commit a speech act). The last component is specific to each particular SBP: it can express the content of request or advice, the cause for apology, the reason for INVITATION, etc. Each component of the performative formula may have grammatical similarities and differences in each of the compared languages.

\title{
STRUCTURE OF THE SBP OF INVITATION
}

As shown in the analysis, in order to express INVITATION in both languages, German and Russian, the following three types of structural models are most commonly used:

\begin{abstract}
explicit performative models with and without modalization: Ich möchte dich zum Essen einladen [I would like to invite you to dinner]; Priglašaem Vas na jubilejnye toržestva v Kremljovskom dvorce [We invite you to the anniversary celebrations at the Kremlin Palace]; implicit performative models in the form of declarative and interrogative sentences: Wir würden uns freuen, Sie bei uns begrüßen zu können [We would be pleased to welcome you to us]; Hast du Lust mitzukommen? [Do you want to come along?]; Sočtu za čest', esli Vy pridëte ko mne na svad'bu [I would be honoured if you would come to my wedding]; Ne soglasiš'sja li ty použinat' so mnoj? [Would you agree to have dinner with me?]

models with imperative constructions: Komm, tanz mit mir! [Come dance with me!]; Prihodi zavtra ko mne na Den' roždenija [Come to my birthday tomorrow].
\end{abstract}

The prototypicity of the model that realizes INVITATION depends on the language, as it will be shown subsequently.

Explicit performative model. In the case of INVITATION, the explicit performative model most commonly includes all four components of the prototypical performative formula:

- component of Action, which, in particular, expresses the communicative purpose of INVITATION;

- component of Speaker, which indicates who makes an INVITATION,

- component of Hearer, which shows who the INVITATION is addressed to,

- component of Reason, which explains the motive for the INVITATION.

All four components are necessary for the hearer to receive a sufficient amount of information and decide how to handle the INVITATION.

The component of Action contains the performative verb in the first person singular or plural. In this SBP, plural forms are quite frequent, because the Speaker component can include entire families, co-workers and other groups of people interested in the action.

The component of Speaker is conveyed by a corresponding personal pronoun or, as in Russian, by corresponding personal endings of the performative verb, cf. examples (5) and (6).

The component of Hearer in both languages is expressed with the help of a personal pronoun (exs. 5 and 6) or a noun (ex. 7) in the Accusative case.

The component of Reason is expressed in most cases either by a verb in the infinitive form (or by an infinitive group) (as in 5 and 6) or by a prepositional phrase. In German, such a prepositional phrase contains the preposition $z u+$ Dative (7), whereas in Russian, it is $n a+$ Accusative (8):

Wir laden Sie ein, an unserem Nationalfest teilzunehmen. [We invite you to participate in our national festival.]

\footnotetext{
${ }^{5}$ The term performative formula is used in Searle's (1965) sense; cf. also Hindelang (2004, p. 23).
} 
(6) Priglašaem vas prisylat' naučnyj fol'klor $k$ nam v redakciju. [We invite you to send scientific folklore to our editorial office.]

(7) Ich lade alle Bürger zur Glockenweihe am Sonntag um 11 Uhr ein. [I invite all citizens to the bell consecration on Sunday at 11 o'clock.]

(8) Priglašaem Vas na tradicionnyj škol'nyj prazdnik “Za čest’ školy”. [We invite you to the traditional school holiday "For school's honor".]

In addition to the typical cases, however, the Reason component may also be expressed by means of finite verb forms (10), imperative sentences (9), periphrases (11), etc.:

(9) Ich lade Sie ein: Folgen Sie unserem Olma-Motto "Schmeck den Süden Deutschlands". [I invite you: Follow our Olma-motto "Taste the South of Germany".]

(10) Ja tebja priglašaju: posidim za butyločkoj vina, pogovorim o tom, o sëm. [I invite you: let's sit with a bottle of wine, talk about this and that.]

(11) Tovarišč Davydov, u nas nynče svad'ba, priglašaem vas vsem semejstvom. [Comrade Davydov, we have a wedding in the coming days, we invite you and all your family.]

In the case of LOCUS INVITATION, one must also indicate the place where the upcoming activity is going to take place, as well as the time of the activity, if this is not clear from the communicative situation:

(12) Herr Grabb, ich lade Sie gerne zu einem Stück Kuchen und einer Tasse Kaffee auf meiner Terrasse zu der Hauptverkehrszeit, etwa um $16 \mathrm{Uhr}$, ein. [Mr Grabb, I would like to invite you to a piece of cake and a cup of coffee on my terrace at rush hour, around $4 \mathrm{PM}$.]

(13) Ja priglašaju tebja na obed segodnja $k$ vos'mi časam večera v "Aragvi”. [I'm inviting you for a dinner today at 8 o'clock in the evening at "Aragvi".]

The performative formula can also be modalized. In this case, the declarative sentence contains the modal verbs wollen/mögen and hotet' in the subjunctive or indicative form, respectively:

(14) Ich möchte dich gerne einladen, an unserem Reconquista-Projekt teilzunehmen. [I would like to invite you to participate in our Reconquista project.]

(15) Ja hoču priglasit' vas sjezdit' ko mne na paru časikov. [I would like to invite you to go to my place for a couple of hours.]

In interrogative sentences, the modal verbs können and moč' are used (in Russian, the modal verb is often in the negated form as in example 17):

(16) Sagen Sie, kann ich Sie zu einem Kaffee einladen? Dann erzählen Sie mir alles. [Tell me, can I invite you for a cup of coffee? Then you'll tell me everything.]

(17) Prostite, no mne neudobno, ne mogu li ja priglasit'Vas $k$ sebe domoj na čašku kofe? [Excuse me, I am sorry to ask, can I invite you to my house for a cup of coffee?]

Implicit performative model. The non-imperative implicit performative model is expressed either by a declarative sentence or by an interrogative sentence.

With the help of a declarative sentence, the speaker states his anticipation with regard to the future mutual activity: 
(18) Es wäre schön, Sie wieder einmal bei uns im Lunaris begrüßen und verwöhnen zu dürfen. [It would be nice to welcome and take care of you once again in Lunaris] My byli by rady videt' vas zavtra na piknike. [We would be happy to see you at the picnic tomorrow.]

With the help of an interrogative sentence, the speaker wants to clarify whether the hearer wants to accept the INVITATION:

Hast Du Lust, zwei Wochen Aktivferien am Ufer des Lago Maggiore zu genießen? [Do you want to enjoy two weeks of active holidays on the shore of Lago Maggiore?] Slušaj, Kudelin, ne soglasišs'sja li ty poobedat' so mnoj? [Listen, Kudelin, would you agree to have lunch with me?]

Models with imperative constructions. In accordance with the general tendency of the directive SBPs, this model is mostly typical for the Russian language. It is mainly used in LOCUS INVITATION, i.e., when the speaker invites the hearer to go or come somewhere. Accordingly, verbs used in the imperative form in this case usually denote a kind of movement: prihodi(te), zahodi(te), priezžaj(te), poedem(te), etc.:

(22) Obraščajas' k brigadiru, vdrug skazal. - Priezžaj ko mne v Dzaudžikau. Gostem budeš’’. [Addressing the foreman, he suddenly said. - Come to my place in Dzaudžikau. You'll be my guest.]

As shown in the corpus study, in German, the use of imperative forms in the realization of INVITATION is also possible (cf. examples 23 and 24), but it is not as widespread as in Russian. However, in Russian, such expressions are mainly used in unofficial communication.

Komm zu mir als Art-Direktor, ich zahl dir das Doppelte. [Come to me as an art director, I'll pay you double.]

Kommen Sie heute zwischen 14 und 17 Uhr zum Grünen Wochenmarkt am Hauptbahnhof. [Come today between 2 and $5 \mathrm{pm}$ to the weekly green market at the main station.]

The communicative purpose of INVITATION can only be derived from the propositional content. If the context is not clear, the utterance can also be understood as a request or a proposal.

\section{COMMUNICATIVE-PRAGMATIC FACTORS}

\section{SOCIAL, CULTURAL AND SITUATIONAL FACTORS}

All non-verbal factors that influence the process of selecting linguistic forms for the realization of communicative purpose can be divided into three broad groups: social, cultural and situational.

Social factors are connected with the personality of interactants and reflect their position in the social sphere. Here belong various characteristics of communicating individuals, first of all, the following:

- social status of interlocutors, i.e., their belonging to a certain social group, profession, position, education level, family status, etc.;

- social distance between interlocutors: zero, neutral, or close relations; 
- bio-physiological characteristics of interlocutors, first of all, their sex and age;

- degree of acquaintance between interlocutors.

Cultural factors are connected with cultural specifics of the society to which interactants belong. They find its expression in traditions, customs and cultural norms. The most important of them include:

- norms of etiquette, i.e., general traditional rules dictating behaviour patterns in a society;

- norms of politeness ${ }^{6}$ that regulate relations between interlocutors in a given situation;

- social stereotypes, i.e., a standardized opinion on certain social groups or representatives of these groups.

Situational factors belong directly to the situation in which communication takes place. These include:

- time and place of event;

- connection of speech act with other utterances;

- current psychological state of interlocutors, i.e., their mood, current knowledge, objectives and interests, etc.

It is important to understand that many of these factors bear national specifics. For example, the degree of influence of the age factor or the social status factor on speech behaviour can substantially vary in Eastern and Western countries, the rules of speech etiquette and ideas of politeness are not the same in different communication societies, too (cf. Larina 2009).

When determining the overall strategy of behaviour, the situational factors are subordinated to the first two groups of factors. Halliday (1973, p. 49) describes their correlation as follows: "The context of culture defines the potential, the range of possibilities that are open. The actual choice among these possibilities takes place within the given context of situation". Thus, the social and cultural factors outline the range of SBPs to be chosen by the speaker, while the situational factors determine the specific pattern in the given communicative situation.

\section{COMMUNICATIVE-PRAGMATIC FACTORS IN THE SBP OF INVITATION}

Situations in which the SBP of INVITATION is realized in German and Russian, as well as what specifics should be taken into account, depends on the general cultural differences and politeness concepts. Kecskes (2015, p. 186) speaks in this context of 'ethnically marked communication styles' (cf. also Goddard, 2006 and other works on ethnopragmatics).

In the Russian culture, the rules of politeness are conditioned by the influence of solidarity politeness, which is a priority in Slavic societies (cf. Rathmayr, 1996, p. 178-185; Larina, 2009). Accordingly, the speaker feels entitled to pronounce the INVITATION directly and categorically, because he is fairly certain that the hearer shares the speaker's anticipation of the upcoming activity and that the INVITATION is pleasant to him (Larina 2009, p. 236-239). Russian communicants can even express their INVITATION with a certain forcefulness, which is not acceptable in German:

\footnotetext{
${ }^{6}$ The notion of politeness is undoubtedly very closely connected with the notion of speech etiquette. However, it would be a mistake to equate these two notions. While speech etiquette defines the rules of behaviour and consequently the use of appropriate linguistic expressions in certain given situations, politeness is directed at mutually respectful treatment between interlocutors. The rules of etiquette are not equal to the moral rules. Politeness consists in the use of language means and speaking strategies that signal the addressee that the speaker treats him well and respects his personal sphere.
} 
(25) Feliks, ja hoču priglasit' tebja na čašečku kofe. I predupreždaju, čto otkaza ne prinimaju. [Felix, I want to invite you for a cup of coffee. And I warn you that I won't accept refusal.]

In the German culture, the politeness rules are influenced by distance politeness (cf. Rathmayr, 1996, p. 178-185), therefore the Germans generally strive to avoid any intrusiveness in the INVITATION, especially in oral communication (cf. Yakovleva, 2004, p. 308-310). For this purpose, modalized utterances and indirect speech acts in the form of declarative (ex. 26) and interrogative sentences (ex. 27) are employed:

(26) Ich wäre sehr froh, wenn Sie mitfahren würden. [I would be very happy if you would go with me.]

(27) Vielleicht kannst du heute Abend kommen und mit uns was trinken? [Maybe you can come and have a drink with us tonight?]

If the INVITATION in German is expressed too indirectly, the Russian communication partners may doubt whether it is sincere and whether the INVITATION should be accepted. The German conversation partners, on the other hand, may feel themselves under pressure in the case of forceful Russian INVITATIONS, and therefore they may not feel comfortable (cf. Yakovleva, 2004, p. 309).

Another difference, which is based on the comparison of the politeness concepts in both cultures, refers to the commitment and timeliness of LOCUS INVITATION. In Germany, it is not customary to come without INVITATION, because an unexpected visit can disturb the private sphere and the freedom of action of the persons to be visited. In Russia, on the other hand, visitors assume that their good acquaintances are always glad to meet them, so in the case of close relations an INVITATION is not absolutely necessary. Besides, in the Russian culture LOCUS INVITATION can be made at a very short notice (cf. ex. 28). In Germany, there must be enough time between the INVITATION and the planned activity in order to allow the invited visitor to plan the upcoming visit and activities accordingly.

(28) I tut Sveta proiznosit: “Dima, prihodi zavtra ko mne na den' roždenija. Ja tebja priglašaju” [And then Sveta says: "Dima, come to me for birthday tomorrow. I'm inviting you."]

Formulation of the INVITATION is also somewhat dependent on such pragmatic factors as age and social distance. Younger communicants, as well as communicants with a small social distance, prefer to use shortened forms when formulating INVITATION. In Russian, these are predominantly single imperatives or short imperative constructions such as zahodi (ko mne), prohodi(te), zabegaj(te), etc. The prefix za-emphasizes the short-term nature and the casualness of the action. In German, one usually uses the particle mal in this case: Komm mal vorbei, Du kannst mich mal besuchen and so on.

\section{THE ORGANIZING STRUCTURE OF SBP: COMMUNICATIVE-PRAGMATIC FIELD APPROACH}

\section{DESCRIPTIVE AND COMPARATIVE ANALYSIS USING THE FIELD APPROACH}

For a better visual representation, when describing the composition and structure of SBPs, the field approach is used. The principle of a field was put into linguistic usage in the $30 \mathrm{~s}$ of the $20^{\text {th }}$ century. It proved to be a very productive way of representing relations that exist between 
the elements of the language system. The field approach helps to depict the interaction of various means belonging to different language levels that are used to express a certain meaning as well as the correlation between the content plane and the expression plane of any language units.

In this sense, the field is an efficient basis for contrastive studies. In the process of comparing languages, the semantic invariant of the field serves as the third member of the comparison (Tertium Comparationis), while the means of expression reflect the specifics of the field organisation in each compared language. The most important characteristic of the field is the division of language units according to the centre - periphery principle.

Thus, field is understood as a certain group of linguistic elements that exhibit relations and interdependence with each other. The fundamental idea remains the same - linguistic elements that have some common property (either formal, or semantic, or functional) can be arranged according to the field principle (cf. Sommerfeldt et al., 1991, p. 5):

- maximum concentration of specific characteristics (CENTRE) - less specific characteristics (PERIPHERY);

- maximal functional load (CENTRE) - lesser functional load (PERIPHERY);

- maximum specialization of the relevant linguistic means for realization of a certain function (CENTRE) - secondary role in the realization (PERIPHERY).

In the current case, it is the communicative purpose of SBP that can be regarded as the dominant of the field. This approach gives us a possibility to unite all available forms expressing SBP with a certain communicative purpose in languages under comparison into a field. In what follows, the communicative-pragmatic field (CPF) is defined.

Applying the field concept to the analysis of forms realizing SBP can make a significant contribution to the development of the theory of speech acts and their contrastive study, since by means of the field model one can identify systemic correlations between the elements and its functional relationship. That way one can easily demonstrate paradigmatic and syntagmatic relations between the elements.

CPFs unite diverse sets of grammatical, lexical, word-formational, topological, and prosodic means serving to express a certain communicative purpose (for example, REQUEST, GREETING, APOLOGY, WARNING, etc.). Thus, CPF is the unity of the communicative purpose of SBP and forms of its realization.

The composition of CPF is ethnoculturally determined. The same communicative purpose can be expressed by different means in different languages and cultures. The distribution of the language means within the field may depend on a particular language. In this sense, the field model is a fruitful tool for contrastive analysis. This can be illustrated, for example, by the results of the contrastive analysis of the SBP of CONGRATULATION in German and Russian performed using the CPF approach. The analysis revealed an important difference between the two languages: in the German language, the field core alongside with explicit performatives basically contains implicit ones like Ich wünsche dir ein frohes Weihnachtsfest! ['I wish you a Merry Christmas!'], while in the Russian language, it is explicit performatives (pozdravljat' 'congratulate') that prevail, e.g.: Pozdravljaju tebja s Roždestvom! ['(I) congratulate you to the Christmas'].

Interestingly, in contrast to German and Russian, where the performative verb congratulate / pozdravljat' can be used for birthday wishes, the Polish verb equivalent gratulować is never used in this situation, it is used only when the event is a result of the addressee's effort, e.g., Serdecznie gratuluję ukończenia szkoły z wyróżnieniem ['(I) congratulate [you] sincerely with the graduation from the school with distinction']. 


\section{FORMS EXPRESSING THE CPF OF INVITATION}

Central forms of realization. In a typical INVITATION, the speaker wants to emphasize that he assumes the responsibility that the upcoming activity is going to be successful and pleasant for the hearer. Therefore, the use of the performative formula with the verb einladen and priglašat', respectively, is prototypical for this SBP and is thus central with regard to the field structure:

(29) Wir laden Sie ein, am 24. und 25. Oktober in das St. Mangen-Quartier zu kommen.

[We invite you to come to the St. Mangen district on 24 and 25 October.]

(30) Ja priglašaju vseh, kto razdeljaet moi ubeždenija, $k$ sotrudničestvu. [I invite everyone who shares my beliefs to cooperate.]

The lexical intensifiers used in this pattern are not numerous. They include adverbs and expressions such as aufrichtig, herzlich, vom ganzen Herzen, and iskrenne, serdečno, ot vsego serdca:

(31) Wir laden Sie ganz herzlich ein, mit an Bord zu kommen. [We cordially invite you to come on board.]

(32) Ja ot vsego serdca priglašaju Vas na konferenciju "Ogon' na Altare” v Čikago. [I invite you from the bottom of my heart to the conference "Fire on the Altar" in Chicago.]

The nominal variant of the performative formula with the synonymous noun is represented only by the construction nehmen Sie meine Einladung an and primite moë priglašenie:

(33) Nehmen Sie bitte meine Einladung an, hier ein bisschen Zeit zu verbringen und meine Art der Fotografie kennenzulernen. [Please accept my invitation to spend some time here and get to know my kind of photography.]

(34) Sdelajte mne čest', primite moe priglašenie poobedat'vmeste u Testova. [Do me the honor of accepting my invitation to dine together at Testov's.]

However, in both languages, these constructions belong to the official style and therefore are mainly used in written communication.

The core of the Russian CPF also includes imperative forms, which act as direct demands. According to Larina (2009, p. 245), when realizing INVITATION, the Russian communicants use utterances with single imperatives or other imperative constructions in 41 percent of the cases.

In German, imperative expressions are also rather widespread, i.e., they belong to the central realization forms of INVITATION. However, they cannot be counted as belonging to the actual core of the field, because in most cases the Germans prefer explicit performative utterances, cf. the usual invitation form in Russian (35) and the corresponding translational equivalent in German (36):

(35) Prihodi ko mne na den' roždenija. Prosto tak. Podarok - eto to, čto ty pridëš. [Come to my birthday. Just like that. The gift is that you come.]

(36) Ich lade dich zu meinem Geburtstag ein. Einfach so. Das Geschenk ist, dass du kommst. [I'm inviting you to my birthday. Just like that. The gift is that you come.]

Constructions with the verbs erlauben, gestatten and razrešat', pozvoljat' in the imperative form used with the infinitive of the performative verb represent a special group: 
(37) Erlauben Sie mir, Sie einzuladen. Barkeeper, eine Lokalrunde! Und natürlich auch ein Glas für Sie. [Allow me to invite you. Bartender, a round for the house! And of course, a glass for you.]

(38) Pozvol'te vas priglasit' dlja prijatnoj progulki po naberežnoj. [Would you allow me to invite you for a pleasant walk along the strand?]

Another quite common model in Russian is the one with the particle davaj(te), which, as in PROPOSAL, serves to express the inclusive imperative:

(39) Znaeš' chto, davaj segodnja pojdëm ko mne, budem pit' čaj s mëdom i čitat' stihi. [You know what, let's go to me today, we'll drink tea with honey and read poetry.]

Short invitation forms as zabegaj, zagljadyvaj, zaskakivaj, belonging to the colloquial style in Russian are often used as farewell phrases, cf.:

(40) Esli čto, zabegaj, - s udručiv̌sej Margo bodrost'ju uže v dverjah naputstvovala eё hozjajka. [Drop in, if anything - with cheerfulness, which depressed Margo, the landlady addressed her, when she was already standing in the door.]

(41) Kivnuv v storonu dveri, on toroplivo sunul mne ruku. - Zaskakivaj zavtra. [Nodding toward the door, he hurriedly gave me his hand. - Drop by tomorrow.]

Implicit performatives, especially in the form of declarative sentences, assume a transitional position between the centre and the periphery of the CPF in both languages, because they are not very common in unofficial communication. In the official style, there are expressions such as:

(42) Wir würden uns freuen, Sie auch morgen wieder an dieser Stelle begrüen zu dürfen. [We would be pleased to welcome you to this place again tomorrow.]

(43) Esli Vy svobodny, ja byl by sčastliv vstretit'sja s Vami v teatre. [If you are free, I would be happy to meet you at the theatre.]

In unofficial communication, one usually employs others constructions in the same situational context, cf. the following examples (44) and (45) with (42) and (43), respectively.

(44) Wir laden Sie auch morgen hierher ein! [We invite you here tomorrow as well!]

(45) Prihodi večerom v teatr, esli smožeš'. [Come to the theatre in the evening, if you can.] following:

Peripheral forms of realization. Among the peripheral forms one can distinguish the

(a) Stylistically marked synonyms of the performative expressions.

There are other verbs in both languages that can be used in the performative function in the case of INVITATION to dance or to perform some artistic activity, namely, engagieren and angažirovat'. These verbs are of the French origin and they are synonymous to einladen and priglasit'. Today they are stylistically marked as outdated, especially in Russian:

(46) “Ich wag's”, stößt er endlich hervor, dicht vor Lore stehenbleibend. "Ich engagiere Sie". ["I dare to do it", he finally pushes out, stopping close to Lore. "I engage you".]

(47) Ja taki opjat' imeju čest' vas angažirovat' pour mazure. [I have the honor again to engage you pour mazure.] 
The phrases as habe die Ehre, Sie einzuladen and imeju čest' priglasit' Vas belong to the elevated style. In everyday communication, however, these expressions can also be used ironically:

(48) Ich habe die Ehre, Sie einzuladen in die Vorstellungen von „Aladin und die Wunderlampe". [I have the honour to invite you to the performances of "Aladdin and the Magic Lamp".]

(49) On podošël i toržestvenno-ironičeski proiznës: "Imeju čest' priglasit' vas na svad'bu, kotoraja sostoitsja 13 janvarja 1970 goda". [He approached and said both solemnly and ironically: "I have the honor to invite you to the wedding, which will be held on January 13, 1970.”]

(b) Indirect means realizing INVITATION.

Indirect means of expressing INVITATION are quite rare, because the speaker wants to clearly express his intention to care for the well-being of the hearer.

To indirect means can belong, first of all, modalized declarative sentences in the indicative and subjunctive form. In order to modalize, the verbs wollen / mögen and hotet' are used:

(50) Meine Mutter und Schwester freuen sich, dich zu sehen. Ich möchte gern, dass du kommst. [My mother and sister are happy to see you. I would like you to come.]

(51) 11 avgusta u menja svad'ba. Hoču videt' vas na našem toržestve. [On the $11^{\text {th }}$ of August, I have a wedding. I want to see you at our celebration.]

These statements, however, are difficult to distinguish from general demands.

In addition, INVITATION can be indirectly expressed by modalized interrogative sentences with and without negation. While non-modalized sentences act as implicit performatives, because in this case the communicative purpose is clearly expressed, the modalized questions distinguish two communicative purposes (or illocutionary acts in Searle's terms) - primary and secondary:

(52) Wäre es möglich, Sie für den Zeitraum des kommenden Monats als Gast zu empfangen? [Would it be possible to welcome you as a guest for the the upcoming month?]

(53) Možet byt', nam udastsja uvidet' vas v naših krajah sovsem skoro? [Maybe we will be able to see you in our area very soon?]

(54) V voskresen'e krestiny moego vnuka. Ne mog by ty počtit' nas svoim prisutsviem? [On Sunday, my grandson will be christened. Could you honor us with your presence?]

In examples (52), (53) and (54), the illocutionary act of the question is secondary and the utterances function primarily as INVITATIONS.

\section{CONCLUSION}

The present article proposes and showcases a novel methodology for describing cross-cultural communication based on the four-step analysis of speech behaviour patterns. A speech behaviour pattern (SBP) is considered to be a basic unit of communication within this approach. The article demonstrates how this methodology can be applied to the analysis of the SBP of INVITATION in German and Russian. This SBP was analysed using the following procedure: 1) defining illocutionary purpose of the SBP with the help of Natural Semantic 
Metalanguage, 2) describing structural forms of the SBP, 3) identifying communicativepragmatic factors affecting the SBP, and 4) describing the structure and hierarchy of the communicative-pragmatic field that includes utterances implementing the SBP. The resulting description of this SBP in both languages provide some insights into similarities and differences between these two language cultures. Firstly, the prototypical means of realization of INVITATION in both languages belong the performative formula with the verbs einladen and priglašat'; these forms are central with respect to the communicative-pragmatic field structure. This is due to the fact that with INVITATION the speaker typically wants to point out that he assumes responsibility for the upcoming activity. Secondly, in Russian, however, imperatives belong to the communicative-pragmatic field core, whereas in German imperatives assume a transitional position between the centre and the periphery of the field. Thirdly, in both languages, the peripheral means realizing INVITATION include modalized declarative sentences in the indicative and subjective mood, as well as modalized interrogative sentences with or without negation. Finally, the analysis also reveals that communicative-pragmatic differences are conditioned by culture-related specifics. For representatives of the Russian culture, which is oriented towards solidarity politeness, it is quite common to formulate INVITATION in a categoric manner. This is not typical of German speakers, as the German culture is oriented towards distance politeness. This difference also finds its reflection in the fact that in the Russian culture, LOCUS INVITATION can be made at short notice before the planned activity. In the German culture, there must be a sufficient amount of time between the INVITATION and the planned activity.

The main advantage of the proposed methodology of comparative analysis of SBPs presented in this article is that it does not concentrate on a single aspect influencing the implementation of SBP, but offers a framework for a comprehensive cross-cultural analysis that includes both cultural, linguistic and pragmatic factors. This methodology is universal and can be successfully applied both for the analysis of other SBPs and for the comparison of other pairs or groups of languages.

\section{REFERENCES}

Bakhtin, M. M. (1996). Problema rečevyh žanrov [Problem of speech genres]. In Bakhtin M.M. Sobranie sočinenij. Tom 5: Raboty 1940-1960 gg. [Bakhtin M.M. Collected works. Vol. 5: Works in the period of 1940-1960] (pp. 159-206). Moscow: Russkie slovari.

Blum-Kulka, Sh. \& Olshtain, E. (1984). Requests and Apologies: A Cross-Cultural Study of Speech Act Realization Patterns (CCSARP). Applied Linguistics. Vol. 5(3), 196-213.

Bührig, K. (2005). "Speech action patterns" and "discourse types". Folia Linguistica. Vol. 39(1-2), 143-171.

Catana, S. E. (2014). Teaching cross-cultural communication issues - a way of successfully integrating into the multicultural knowledge society. Procedia - Social and Behavioral Sciences Vol. 128, 343-348.

Dönninghaus, S. (2001). Sprechakt und Kommunikationsgenre (Theoretische Aspekte der sprachlichen Interaktion). Beiträge der Europäischen Slavistischen Linguistik (POLYSLAV). Bd. 4, 69-79.

Drid, T. (2018). Language as action: Fundamentals of the speech act theory. Praxis International Journal of Social Science and Literature. Vol. 1(10), 2-14.

Faraco, C. A. (2017). Bakhtin e filosofia. Bakhtiniana: Revista de estudos do discurso [Bakhtiniana: Journal of Discourse Studies]. Vol. 12(2), 45-57.

Gladrow, W. \& Kotorova. E. (2017). Kontrastive Untersuchung von Sprachhandlungsmustern. Zeitschrift für Slawistik. Vol. 62(3), 366-387. 
Goddard, C. \& Wierzbicka, A. (2016). Words, meaning, and methodology. In C. Goddard \& A. Wierzbicka (Eds.). Words and Meanings. Lexical Semantics Across Domains, Languages and Cultures (pp. 1-21). New York: Oxford University Press.

Goddard, C. (2006). Ethnopragmatics. A new paradigm. In C. Goddard (Ed.). Ethnopragmatics. Understanding discourse in cultural context (pp. 1-30). Berlin: de Gruyter.

Halliday, M. A. K. (1973). Explorations in the functions of language. London: Edward Arnold.

Harras, G., K. Proost \& E. Winkler (2007). Handbuch deutscher Kommunikationsverben. Teil II: Lexikalische Strukturen. Berlin etc.: Walter de Gruyter.

Hindelang, G. (1978). Auffordern. Die Untertypen des Aufforderns und ihre sprachlichen Realisierungsforman. Göppingen: Verlag Alfred Kümmerle.

Hindelang G. (2004). Einführung in die Sprechakttheorie. Tübingen: Max Niemeyer.

Kasper, G. \& Roever, C. (2005). Pragmatics in second language learning. In E. Hinkel (Ed.). Handbook of research in second language teaching and learning (pp. 317-334). New Jersey: Lawrence Erlbaum Associates.

Kecskes, I. (2015). Intracultural communication and intercultural communication: Are they different? International Review of Pragmatics. Vol. 7, 171-194.

Larina, T. V. (2009). Kategorija vežlivosti $i$ stil' kommunikacii. Sopostavlenie anglijskih $i$ russkih lingvokul'turnyh tradicij [Category of politeness and style of communication. Comparison of the English and Russian linguo-cultural traditions]. Moscow: Jazyki slavjanskih kul'tur.

Lifintsev, D. \& Wellbrock, W. (2019). Cross-cultural communication in the digital age. Estudos em Comunicação. Vol. 1(28), 93-104.

Lulu, R.A. \& Alkaff, S.N.H (2019). A Cross-Cultural Study of Persuasive Strategies in Relationship Advice Articlesin Women's Magazines. GEMA Online Journal of Language Studies. Vol. 19(2), 15-32.

Lyons, J. (1995). Linguistic semantics: An introduction. Cambridge: Cambride University Press.

Merkin, R., Taras, V. \& Steel, P. (2014). State of the art themes in cross-cultural communication research: A systematic and meta-analytic review. International Journal of Intercultural Relations. Vol. 38, 1- 23.

Murphy, B. \& Neu, J. (1996). My grade's too low: The speech act set of complaining. In S. M. Gass \& J. Neu (Eds.), Speech acts across cultures: Challenges to communication in second language (pp. 191-216). Berlin: Mouton de Gruyter.

Nuyts, J. (2016). Analyses of the modal meanings. In J. Nuyts \& J. Van Der Auwera, (Eds.). The Oxford Handbook of Modality and Mood (pp. 31-49). Oxford: Oxford University Press.

Olshtain, E. \& Cohen, A. D. (1983). Apology: A speech act set. In N. Wolfson \& E. Judd (Eds.). Sociolinguistics and language acquisition (pp. 18-35). Rowley, MA: Newbury house.

Purkert, U. (1990). Das Kommunikationsverfahren EINLADEN in russischsprachigen Texten. Potsdamer Forschungen, Reihe A, H. 106, 153-160.

Rathmayr, R. (1996). Höflichkeit als kulturspezifsches Konzept: Russisch im Vergleich. In I. Ohnheiser (Ed.). Wechselbeziehungen zwischen slawischen Sprachen, Literaturen und Kulturen in Vergangenheit und Gegenwart (pp. 174-185). Innsbruck: Verlag des Instituts für Sprachwissenschaft der Universität Innsbruck.

Searle, J. R. (1965). What is a speech act? In Maurice Black (Ed.), Philosophy in America (pp. 221-239). London: Allen and Unwin.

Searle, J. R. (1979). Expression and meaning: Studies in the theory of speech acts. Cambridge: Cambridge University Press. 
Sommerfeldt, K.-E., Schreiber, H. \& Starke, G. (1991). Grammatisch-semantische Felder. Einführung und Übungen. Berlin, München: Langenscheidt.

Suchankova, H. (2014). Developing Intercultural Competences during the Language Tuition. Procedia - Social and Behavioral Sciences. Vol. 116, 1439-1443.

Vežbickaja, A. [= Wierzbicka, A.]. (1999). Semantičeskie universalii i opisanie jazykov [Semantic universals and language description]. Moscow: Jazyki russkoj kul'tury.

Wagner, K. (2001). Pragmatik der deutschen Sprache. Berlin etc.: Peter Lang Verlag.

Wierzbicka, A. (1983). Genry mowy [Speech genres]. In T. Dobrzyńska \& E. Janus (Eds.). Tekst i zdanie. Zbiór studiów [Text and sentence. Collection of studies] (pp. 125-137). Wrocław etc.: Ossolineum.

Wierzbicka, A. (1985). A semantic metalanguage for a crosscultural comparison of speech acts and speech genres. Language and Society. Vol. 14, 491-513.

Wierzbicka, A. (1987). English speech act verbs: A semantic dictionary. Sydney etc.: Academic Press.

Witczak-Plisiecka, I. (Ed.) (2014). Cognitive and pragmatic aspects of speech actions. Berlin etc.: Peter Lang Verlag.

Yakovleva, E. (2004). Deutsche und russische Gespräche. Ein Beitrag zur interkulturellen Pragmatik. Tübingen: Max Niemeyer Verlag.

\section{CORPORA}

Nacional'nyj korpus russkogo yazyka [National Corpus of the Russian Language]. Retrieved November 10, 2020 from http://www.ruscorpora.ru

DWDS-Korpus. Retrieved November 10, 2020 from https://www.dwds.de/d/korpora

IDS-Korpora Retrieved November 10, 2020 from http://cosmas2.ids-mannheim.de/cosmas2web.

\section{ABOUT THE AUTHOR}

Elizaveta Kotorova is a full professor at the University of Zielona Góra (Poland) and a professor at National Polytechnic University in Tomsk (Russia). Her areas of research interests include lexical semantics, pragmalinguistics, contrastive linguistics, interlingual equivalence, indigenous languages of Siberia (Ket). 